\title{
Introspection on the Rural Land Contractual Management Right Investment
}

\author{
Lin Zhang \\ College of Economics and Management \\ Zaozhuang University \\ Zaozhuang 277100, China
}

\begin{abstract}
The Rural Land Contractual Management Right Investment is a new way of farmland circulation. It helps enterprises to become the main body of agricultural operation, and helps capital open the way into agriculture. Based on the experience of foreign countries and the adverse consequences of the investment operation, this paper holds the view that the Rural Land Contractual Management Right Investment not only can't be popularized in a large area, but also must be standardized and rectified.
\end{abstract}

Keywords-The Rural Land Contractual Management Right Investment; Foreign experience; Adverse consequences

\section{INTRODUCTION}

In recent years, the Rural Land Contractual Management Right Investment has become an important form of farmland transfer in rural practice. It refers to a system arrangement that on the basis of the unchanged household contract responsibility system, the farmer shares the economic contract with the right of land contractual management, and the land is managed by the economic organization, at the same time, the farmers get dividends in the name of shareholders. On the surface, the Rural Land Contractual Management Right Investment is only a market form of rural land transfer, but behind it is concealed fact that farmland is handed over to capitalists. The consequences are worrying [1].

\section{EXTRATERRITORIAL EXPERIENCE AND LESSONS ON THE RURAL LAND CONTRACTUAL MANAGEMENT RIGHT INVESTMENT}

\section{A. Lessons from the Philippines}

In 1946, the Philippines declared independence. The deeprooted colonial ideology, coupled with the extreme dependence on the economy and trade of the United States, led Philippines to follow the way of the United States. The property right system of "the sacred and inviolability of private property" was written into the constitution of the country, and the private property of the land was established. But the private ownership of land in Philippines was established on the basis of the pattern that the big landlords and the big capitalists share the land. Therefore, the countryside land power is that the land was allocated to the big landlords and big capitalists who had absolutely owned the land in the name of law. The peasants' poverty is still unabated. The agricultural production takes the manor and the large farm as the basic unit. Too large and too concentrated is its basic feature. Since 1970s, with the progress of democratization in
Philippines, the contradiction between farmers and big landlords, big capitalists and governments had increased. So all Philippines governments regarded the reform of agriculture as the basis of governance. In 1980s, however, the Philippine agricultural economy came to a standstill and food security became increasingly acute. With the sweeping wave of world agricultural mechanization, the ruling government of Philippines has carried out many reform measures around improving agricultural productivity and promoting the level of agricultural modernization. The capitalization and mechanization level of agricultural production has been greatly improved. Unfortunately, the income of the peasants is not increased, besides this, more and more labors can't find jobs with the popularization of agricultural mechanization. A large number of landless and unemployed peasants have flooded into cities, becoming urban migrants and causing social unrest, which in turn aggravates unemployment and forms a vicious circle. After experiencing half a century of twists and turns, Philippines realized the mistake of agricultural modernization. From the middle of 60 s of last century, it restricted capital management agriculture, at the same time; the Philippine government acquired capitalists' land and distributed it to landless people and farmers. The reform has continued to this day, but the pace of reform has been slow and rapid due to political factors [2].

\section{B. Japanese Experience}

Japan is one of the countries with the largest population density in the world, with per capita cultivated land area of only $0.035 \mathrm{hm} 2$. From 1947 to 1954 , the Japanese government began to implement land ownership reform. The central government compulsorily bought the land of the landlord and then sold it to the sharecroppers at the same price, thus realizing the system of farming in which the tiller has his field. After the Second World War, with the rapid development of economy and the acceleration of industrialization and urbanization, the Japanese government began to carry out the reform of the rural land system centered on land transfer and farmland scale operation. At the beginning of the land transfer, the Japanese government allowed farmers to rent the land to people who are willing to engage in agricultural production. In order to facilitate the transfer and lease of land among farmers, Japan has set up a special agricultural land management company that is not profitable. The agricultural land management company, which is formed jointly by the state, local governments and the farmers' association, is mainly engaged in purchasing or renting agricultural land from 
farmers who are willing to sell and lease agricultural land and then selling these land to people who want to buy or lease land, and the government subsidizes agricultural land management companies and tenants. In order to prevent the land annexation, Japanese laws not only strictly prohibited legal persons from entering agricultural production, but also stipulated that nonagricultural producers could not own agricultural land for up to 15 years. Up to now, Japanese law still restricts the participation of joint-stock companies in agricultural land management, in order to avoid the non-agricultural use of agricultural land by joint-stock companies. The Japanese government has carried out a series of auxiliary system in order to promote land circulation. For example, through vocational training, job introduction and the development of rural industries, the Japanese government provides farmers with opportunities to get out of agriculture. The agricultural pension system was established to solve the worries of farmers who leased land. In addition, a tightly organized agricultural association has been established to make it a powerful intermediary organization between government, market and farmers, to promote cooperation in agricultural management, and to realize the socialization and commercialization of agricultural production. [3]

\section{The Possible Adverse Consequences Of The RURAL LAND CONTRACTUAL MANAGEMENT RIGHT INVESTMENT}

China is in the historical stage of speeding up land circulation. At the end of the 2014, the land transfer area of the country reached 403 million $\mathrm{Mu}$, and the circulation area accounted for $30.4 \%$ of the household contracted management of cultivated land. [4] As a new form of circulation, the Rural Land Contractual Management Right Investment is being popularized all over the country. According to a survey by the Ministry of Agriculture, farmers account for $64 \%$ of the farmland circulation, while industrial and commercial enterprises account for 36\%. [5] It can be seen that among all kinds of business entities, the industrial and commercial enterprises have come to the top of the list, which is a very dangerous signal worthy of attention.

The Basic management system of rural areas may be shaken. Based on the household contract management, the two-tier management system is the basic management system in the countryside of our country. After the implementation of the Rural Land Contractual Management Right Investment, farmers only own the land contract right, and lose the land management right, at the same time, the enterprise has become the main management of the land, and the management level of the family has been abolished, which has shaken the basic management system in the countryside. Especially in some places, the enterprises rearrange the land after it flows into the land. Once the farmers quit the enterprise, it is very difficult to restore the land, which leads to the separation of the relationship between the farmers and the land.
The Phenomenon of forcing farmers to transfer their land may occur. Decision of the CPC Central Committee on Rural Reform and Development of Several Major Issues adopted by the Communist Party of China in the third Plenary Session of the 17th CPC Central Committee clearly put forward to that "according to the principle of law and compensation, farmers should be allowed to transfer the right to land contracted management and develop a variety of forms of moderate scale management". Therefore, the land transfer must be based on the voluntary basis of farmers, and any organization and individual must not force the farmers to transfer the land. But for some local governments, the area of farmland transfer is a political achievement. For grass-roots organizations, they can obtain equity and dividends through farmland transfer. For enterprises, they can enter new business areas and cultivate new profit points through farmland transfer. Therefore, in many parts of China, there is a phenomenon of tripartite joint efforts to speed up the pace of agricultural land transfer, even forcing farmers to transfer land. However, because the rapid development of industrialization, there is not enough jobs for landless farmers, which is bound to threaten social stability in the long run.

The Red line of 1.8 billion $\mathrm{Mu}$ of cultivated land may be impacted. On the surface, the farmer transfers the management right of the land to the enterprise for operation, but in essence, the right to use the land is transferred to the enterprise, making it become the decider of the farmland use. But the strong profit motive led some enterprises to use the land as nonagricultural construction projects and even to develop commercial housing. In order to attract enterprises to participate in the circulation, some local governments not only do not investigate and deal with the business behavior of changing the farmland use of enterprises, but even promise that enterprises can change a certain amount of land into construction land. In addition, because farmers are often able to benefit from non-agricultural projects on the land, they often choose to support illegal use of the land not only increases the contradiction of land regulation but also directly harms the land red line of 1.8 billion $\mathrm{Mu}$.

The Interests of farmers may be damaged. In the enterprise, it is often the village cadres who can represent the peasants into the shareholders' congress, the board of directors and the board of supervisors. It is difficult for ordinary farmers to exercise the rights of democratic management and democratic supervision. In addition, according to the company law, shareholders are not allowed to withdraw their investments at will, which means that it is very difficult for farmers to withdraw their land once they became shareholders. In addition, the stock right can be transferred freely, it also means that the land contract management right of farmers is likely to be transferred to other economic subjects, and worst of all, if the business fails to apply for bankruptcy, it is possible for farmers to lose the land management right after bankruptcy. 


\section{ENLIGHTENMENT}

From the above analysis, we can see that the farmland transfer mode of the Rural Land Contractual Management Right Investment has helped the capital get the access to agriculture, which has occupied the space of the farmers' employment and income. If handled improperly, it may lead to the collusion between local government and enterprises, shake the basic management system in the countryside, and cultivate the new peasant class. Therefore, in the author's view, the farmland transfer mode of the Rural Land Contractual Management Right Investment should not be widely promoted, but should be strictly limited.

Insist on farmers to be the main body of farmland circulation, strictly forbid to accelerate the pace of agricultural land transfer artificially. China's rural population base is too large; the reduction of agricultural population is a continuous and slow process. The farmland transfer mode of the Rural Land Contractual Management Right Investment introduced the power of capital, while speeding up the transfer of farmland, it could not guarantee the rights and interests of farmers, and even the agricultural use of land could not be guaranteed. Therefore, it is necessary to strictly restrict the mode of agricultural land transfer and strictly examine the operating qualifications of agricultural enterprises so as to prevent farmers' interests from being damaged because of their poor management.

The main body of rural land transfer is set as a common farmer, and the enterprise management land is strictly limited. With the acceleration of the industrialization of cities and towns, more and more peasants will leave their homes. The lands which were abandoned by them should be given to other agricultural operators in order to alleviate the contradiction between people and land, increase farmers' income and realize the scale management of farmland. If the enterprises are allowed to operate a large amount of land, the land will become the source of profit of the enterprise rather than the source of the farmer's income. A large number of farmers cannot profit from agricultural labors will become the new class in rural areas, so as to shake the rural basic management system. Therefore, it is necessary to treat the land management right with caution and not relax the conditions of ownership because of the improvement of the short-term income of farmers after the ownership of the shares. In a word, enterprises should be strictly restricted from becoming the main body of agricultural management, and the employment space and income increase space of farmers should be guaranteed.

Cultivate large farmers, farmers' professional cooperatives to become the main land operators. Limiting the rural land contractual management right Investment is not equal to preventing land transfer. At the present stage, we should cultivate large farmers and farmers' professional cooperatives as the main body of rural land transfer. By doing so, farmland operators can obtain stable profits by expanding the scale of agricultural land management while ensuring that farmers become winners of profits. Restricting the entry of capital into the field of agricultural operation does not represent the exclusion of capital. In fact, the development of modern agriculture can't be separated from perfect financial services and sufficient capital guarantee. Therefore, the agricultural labor, land and capital elements can be recombined and allocated through the development of farmers' professional cooperatives.

\section{CONCLUSION}

This paper introduced the current situation of agricultural land circulation and the experience of agricultural land transfer in foreign countries, considered that the mode of the Rural Land Contractual Management Right Investment should not be carried out on a large scale in China at present. Considering the hazards of this model that it is likely to shake the basic agricultural management system, to force farmers to transfer their land, even hit the red line of 1.8 billion $\mathrm{mu}$ of arable land, the paper holds that the implementation of this model should be taken with great care.

\section{REFERENCES}

[1] Wang Lijuan Land Circulation of Representatives Countries(Areas) and Its Apocalypse to China[J].Chinese Journal of Agricultural Resources and Regional Planning,2012,33(4):47-53

[2] Yang T, Zhu B. Results of Rural Land Circulation and the Countermeasures [J]. Research of Agricultural Modernization, 2002.

[3] Xiong J, Zhao R. Rural Land Circulation Problems and Countermeasure Analysis [J]. Agricultural Economics \& Management, 2010, 38(1):179190.

[4] Lian G B. Rural Land Shareholding System - the Optimal Choice of Rural Land Circulation System in China [J]. Journal of Northwest University, 2005.

[5] Xia N, Wang D. An Analysis on the Reform of Rural Land Circulation and Urban-Rural Planning [J]. Urban Planning Forum, 2009, 22(3):8288 . 